\title{
ANALISIS PROFIL MANAJEMEN LABORATORIUM DALAM PEMBELAJARAN KIMIA DI SMA WILAYAH SUMEDANG
}

\author{
Sari $^{1^{*}}$, Dinar Dayana1 dan Ida Farida1 \\ ${ }^{1}$ Program Studi Pendidikan Kimia, Jurusan Pendidikan MIPA, Fakultas Tarbiyah dan \\ Keguruan, Universitas Islam Negeri Sunan Gunung Djati Bandung, Jl. A. H. Nasution No. \\ 105, Bandung, 40614, Indonesia \\ ${ }^{\star} E$-mail: sari@uinsgd.ac.id
}

\begin{abstract}
ABSTRAK
Penelitian ini bertujuan untuk mendeskripsikan profil manajemen dan penggunaan laboratorium pada pembelajaran kimia, meliputi kelengkapan dan penataan alat bahan praktikum, manajemen administrasi dan efektivitas penggunaan laboratorium kimia. Mengingat laboratorium sebagai penunjang pembelajaran kimia juga berperan penting dalam membangkitkan motivasi belajar dan pengembangan keterampilan dalam praktikum. Penelitian ini menggunakan metode deskriptif menggunakan pendekatan kualitatif. Subjek penelitian terdiri dari 2 SMA Negeri dan 1 SMA Swasta di wilayah Sumedang. Pengumpulan data menggunakan metode observasi, angket, dan wawancara. Analisis data menggunakan teknik persentase dengan analisis deskriptif kualitatif. Berdasarkan hasil penelitian, ketersediaan alat praktikum kimia di SMA wilayah Sumedang tergolong kategori lengkap $(69,67 \%)$ dengan kondisi sangat baik (96,6\%), namun ketersediaan bahan praktikum kimia tergolong kategori kurang lengkap $(45,3 \%)$ meskipun dalam kondisi sangat baik (95\%). Penataan alat praktikum kimia tergolong kategori sangat baik $(81 \%)$, sedangkan penataan bahan praktikum tergolong kategori baik (71\%). Administrasi alat bahan praktikum tergolong kategori kurang lengkap (48,6\%), namun penggunaanya sangat efektif (100\%). Administrasi ketenagakerjaan tergolong kategori sangat lengkap (76\%). Efektivitas penggunaan laboratorium di SMA wilayah Sumedang tergolong kategori kurang efektif (42,4\%). Faktor penyebabnya terkait dengan kelengkapan, penataan serta administrasi alat bahan laboratorium dan penjadwalan, selain itu dari sudut pandang guru kimia terkait penting atau tidaknya praktikum dilaksanakan pada beberapa materi.
\end{abstract}

Kata kunci: laboratorium kimia, manajemen laboratorium, pembelajaran kimia

\begin{abstract}
These reasearch was supposted to describe laboratory use at 3 high school in Sumedang. Laboratory have a role to rise development skill when do the laboratory work. This research are used descriptive method with qualitative approach. The subject is 3 high school in Sumedang. The data was collected by using observation, questionnaire and interviews. Data analysis was used percentage technique with analysis descriptive qualitative. Based on the research, availability of tools relatively complete $(69,67 \%)$ in very good condition $(96,6 \%)$, however availability of materials is relatively less of complete $(43,3 \%)$ though in good condition (95\%). Structuring of tools is relatively very good (81\%), while the structuring of material is relatively good (71\%). Administration relatively less of complete (48,6\%). Employement tools is relatively very complete (76\%). The effectiveness of laboratory use at high school in Sumedang is relatively less of effective $(42,4 \%)$. Another factor is from the angle view from the chemistry teacher important or not some lab work was implemented to several material.
\end{abstract}

Keywords: chemistry laboratory, laboratory management, chemistry education

DOI: https://doi.org/10.15575/jtk.v3i1.2593 


\section{PENDAHULUAN}

Kimia merupakan segala sesuatu tentang zat yang meliputi komposisi, struktur dan sifat, perubahan, dinamika, dan energetika zat yang melibatkan keterampilan dan penalaran (Chang, 2008). Ada dua hal yang berkaitan dengan kimia yang tidak bisa dipisahkan, yaitu kimia sebagai produk (pengetahuan kimia yang berupa fakta, konsep, prinsip, hukum, dan teori) dan kimia sebagai proses yaitu kerja ilmiah (Sari et al., 2017).

Mata pelajaran kimia merupakan salah satu mata pelajaran yang memerlukan kegiatan belajar melalui praktikum di laboratorium untuk memenuhi kompetensi peserta didik. Sehingga tidaklah cukup materi kimia disampaikan secara teori saja, perlu juga dilaksanakan praktikum di laboratorium yang memiliki sarana/alat dan bahan-bahan praktikum yang mendukung (Wiratma, 2015). Hal senada juga disebutkan bahwa tujuan dari kegiatan praktikum adalah meningkatkan pengetahuan antara teori dengan pemecahan masalah dan proses sains (Ural, 2016).

Laboratorium membuat pembelajaran lebih bermakna, karena siswa bertindak langsung dalam melakukan pengamatan atas percobaannya (Hofstein \& Lunetta, 2004). Selain itu, keberadaan laboratorium sains di sekolah menengah merupakan keharusan pada pendidikan sains modern, salah satunya laboratorium kimia sebagai bagian dari sains.

Di dalam laboratorium tentunya memerlukan seperangkat alat penunjang kegiatan belajar mengajar, alat penunjang ini terkait dengan alat-alat dan bahan-bahan praktikum (Halida, 2016). Selain itu, perlu adanya manajemen laboratorium agar pelaksanaan praktikum di laboratorium dapat berjalan dengan baik untuk menjadi pembelajaran sains efektif bagi siswa (Hamidah dkk., 2013).

Laboratorium memiliki peran penting dalam membangkitkan motivasi belajar dan pengembangan keterampilan dasar melakukan praktikum (Adisendjaja, 2008). Kegiatan praktikum yang dilakukan di laboratorium merupakan metode yang memberikan pengaruh terhadap keberhasilan siswa dalam belajar kimia (Darmawan, 2014; Adisendjaja, 2008). Selain itu, praktikum memiliki potensi untuk meningkatkan interaksi sosial yang positif sesuai tujuan pembelajaran (Khamidinal, 2009).

Keberhasilan siswa dalam pembelajaran kimia juga kemampuan kognitif terukur dari nilai Ujian Nasional (UN) siswa SMA, di Kabupaten Sumedang pada tahun 2015 ratarata nilai UN untuk mata pelajaran kimia yaitu 52,15 tergolong dalam kategori rendah. Faktor yang menyebabkan nilai UN yang rendah di Kabupaten Sumedang dimungkinkan pelaksanaan praktikum kimia di sekolah belum maksimal. Namun kebenaran akan hal ini harus diteliti lebih lanjut.

Penelitian terkait pengelolaan laboratorium telah dilakukan sebelumnya, oleh Sari dan Yunita (2015) yang meneliti tentang keberadaan laboratorium, pengetahuan alat dan bahan serta keselamatan kerja di laboratorium SMA/MA wilayah Jawa Barat, namun di Sumedang tidak menjadi bagian penelitiannya dengan hasil yang baik $(75 \%)$ untuk pengetahuan alat bahan serta keselamatan kerja di laboratorium. Akan tetapi terkait profil manajemen kelengkapan alat dan bahan, penataan alat dan bahan, administrasi dan efektivitas penggunaan laboratorium kimia di SMA tidak dilakukan. Oleh karena itu, pada penelitian kali ini difokuskan pada keempat aspek tersebut.

Rumusan masalah penelitian ini terkait profil manajemen kelengkapan alat dan bahan, penataan alat dan bahan, administrasi dan efektivitas penggunaan laboratorium kimia. Sehingga tujuan dari penelitian ini yaitu untuk mendeskripsikan profil manajemen dan penggunaan laboratorium kimia di SMA wilayah Sumedang pada keempat aspek tersebut.

Dalam upaya peningkatan kualitas kegiatan belajar mengajar, sangat diperlukan 
laboratorium sebagai tempat berlatih dan untuk mengadakan percobaan serta pengamatan (Khamidinal, 2009), sangat diperlukan dalam rangka peningkatan kualitas kegiatan belajar-mengajar. Laboratorium adalah suatu ruangan tempat melakukan kegiatan praktik atau penelitian yang ditunjang oleh adanya seperangkat alat-alat laboratorium serta infrastruktur laboratorium yang lengkap (Darsana dkk., 2014). Dalam pengertian yang terbatas laboratorium merupakan suatu ruangan tertutup dimana percobaan dan penyelidikan ditunjang oleh adanya perangkat alat-alat dan bahan-bahan yang digunakan untuk kegiatan praktikum (Sagala, 2011).

Laboratorium memerlukan pengorganisasian dan pengelolaan yang baik agar kegiatankegiatan yang berlangsung di dalamnya dapat berjalan sesuai dengan tujuan yang ingin dicapai (Saleh \& Emha, 2006). Menurut Kertiasa (2006) mengelola suatu laboratorium meliputi 4 kegiatan pokok yaitu: 1) mengadakan langkah-langkah yang perlu untuk terus mengupayakan agar kegiatan siswa di dalam laboratorium bermakna bagi siswa dan proses pembelajaran menjadi lebih efektif dan efisien, 2) menjadwal penggunaan laboratorium oleh pengelola agar laboratorium dapat digunakan secara merata dan efisien oleh semua siswa yang memerlukan, 3) mengupayakan agar peralatan laboratorium terpelihara dengan baik, sehingga dapat digunakan dalam waktu yang lama dan selalu siap digunakan, 4) mengupayakan agar penggunaan laboratorium berlangsung dengan aman.

Menurut Koesmadji (2004) pengelolaan laboratorium secara garis besar dibedakan sebagai berikut:

a. Memelihara kelancaran penggunaan laboratorium. Selain diadakan penjadwalan dalam penggunaan laboratorium, diperlukan adanya tata tertib untuk menghindari terjadinya kecelakaan. Perlengkapan P3K dan pemadam kebakaran harus senantiasa ada dalam laboratorium dan setiap pemakai harus mengetahui cara penggunaannya.

b. Menyediakan alat-alat dan zat-zat yang diperlukan dalam laboratorium. Penyediaan zat untuk siswa terdiri dari dua macam yaitu zat yang dapat diambil langsung dan zat yang harus diminta kepada petugas laboratorium.

c. Peningkatan daya guna laboratorium. Setiap akhir tahun ajaran seluruh pengelola laboratorium hendaknya melakukan perencanaan kegiatan laboratorium untuk tahun ajaran berikutnya, sehingga kualitas kegiatan meningkat sesuai dengan bahan dan peralatan yang direncanakan dan disediakan.

Laboratorium tidak akan bermanfaat apabila tidak didukung dengan sarana/alat yang ada di laboratorium untuk melaksanakan praktikum (Barnawi \& Arifin, 2012). Kelengkapan sarana/alat dan bahan di dalam laboratorium diperlukan untuk menunjang kegiatan praktikum di laboratorium. Dalam Permendiknas RI No 24 Tahun 2007 tentang Sarana dan Prasarana dipaparkan bahwa Satu SMA/MA memiliki sarana dan prasarana yang dapat melayani minimum 3 rombongan belajar dan maksimum 27 rombongan belajar. Satu rombongan belajar terdiri dari 15-32 siswa. Kelengkapan alat praktikum berdasarkan silabus kimia Kurikukum 2013 revisi sejumlah 42 alat praktikum yang memadai dalam menunjang kegiatan praktikum. Bahan yang diperlukan untuk menunjang praktikum ada 74 jenis bahan yang terdiri dari asam, basa, garam, logam, dan lain-lain.

Berbagai macam peralatan terdapat di dalam laboratorium (Koesmadji, 2004). Alat yang sering digunakan, alat yang boleh diambil sendiri oleh peserta didik dan alat-alat yang mahal harganya atau alat yang langka sebaiknya disimpan secara terpisah. Alat-alat yang digunakan untuk beberapa jenis percobaan sebaiknya disimpan di tempat penyimpanan khusus (Suprayitno, 2010). Penyimpanan alat berbahan dasar plastik, kaca logam dan karet seperti gelas ukur, tabung reaksi dan sebagainya masing-masing dikelompokkan menjadi satu dan disimpan menurut kelompoknya masing-masing dan 
akan lebih baik jika disimpan terpisah berdasarkan jenisnya sehingga peserta didik lebih mudah menemukan (Yunita, 2013). Alatalat berbahan dasar kaca sebaiknya juga terpisah dengan alat-alat listrik maupun alatalat plastik. Alat yang berat diletakkan di tempat yang mudah dijangkau, alat yang mahal atau yang berbahaya disimpan di tempat yang terkunci (Koesmadji, 2004). Pada dasarnya penyimpanan alat tidak boleh ditempatkan di tempat yang dapat menyebabkan alat itu rusak atau di tempat yang pada proses pengambilan/ pengembaliannya dapat membahayakan pemakainya (Kertiasa, 2006).

Perawatan alat kimia sangat terkait dengan teknik penyimpanan dan penatannya, oleh karena itu untuk melakukan perawatan dan pemeliharaan alat kimia diperlukan pengetahuan penggolongan atau klasifikasi alat kimia (Suprayitno, 2010). Penyimpanan yang baik adalah bagian dari kegiatan perawatan. Di laboratorium terdiri dari berbagai jenis alat kimia yang biasa digunakan untuk praktikum dan memiliki sifat bahan dasar yang berbeda, dengan demikian kegiatan penyimpanan dan penataan harus mendapat pertimbangan khusus (Depdiknas, 2004).

\section{METODE PENELITIAN}

Penelitian ini menggunakan metode deskriptif dengan menggunakan pendekatan kualitatif (Wiersma \& Jurs, 2005), karena pada penelitian ini peneliti berusaha mendapatkan informasi tentang pengelolaan laboratorium dan penggunaannya dalam pembelajaran kimia di SMA wilayah Sumedang. Selain itu, penelitian ini menekankan pada pengumpulan data untuk mendeskripsikan keadaan yang terjadi sesungguhnya dari data yang bersifat kualitatif.

Subjek penelitian ini yaitu tiga SMA wilayah Sumedang yang memiliki laboratorium kimia tersendiri, pemilihannya menggunakan teknik purposive sampling. Dalam pengambilan data digunakan instrumen penelitian berupa lembar observasi serta angket, selain itu untuk melengkapi data juga digunakan pedoman wawancara.

Teknik pengumpulan data pada penelitian ini yaitu dengan cara observasi langsung ke laboratorium kimia di ketiga sekolah yang menjadi subjek penelitian menggunakan lembar observasi kelengkapan alat dan bahan kimia yang telah dibuat serta pemberian angket pada guru dan siswa. Analisis data menggunakan teknik persentase analisis deskriptif kualitatif.

Prosedur dalam penelitian ini dimulai dengan analisis silabus kurikulum 2013 terkait praktikum yang harus dilaksanakan. Dari data praktikum tersebut diidentifikasi alat dan bahan yang harus tersedia di laboratorium sekolah yang selanjutnya dibuat instrumen penelitian terkait manajemen kelengkapan alat dan bahan praktikum serta angket efekivitas penggunaan laboratorium. Instrumen lain terkait manajemen penataan alat dan bahan praktikum serta manajemen administrasi pun dilakukan setelahnya.

Instrumen yang telah dibuat digunakan dalam pengumpulan data di ketiga sekolah yang menjadi subjek penelitian, dilengkapi wawancara dengan pihak sekolah unuk melengkapi data. Data yang dihasilkan dari penelitian yang berupa data kualitatif disajikan dalam bentuk deskripsi sesuai keadaan sebenarnya terkait pengelolaan labratorium di sekolah tersebut.

Penelitian ini menggunakan lembar observasi yang dijadikan sebagai instrumen untuk pengamatan dan pencatatan sistematis dari fenomena-fenomena yang diselidiki terkait manajemen laboratorium. Lembar observasi manajemen kelengkapan alat dan bahan dibuat tabel sejumlah alat-alat praktikum yang digunakan pada praktikum sesuai judul-judul praktikum berdasarkan analisis silabus kimia kurikulum 2013 revisi. Jumlah minimum alat yang dicantumkan dalam lembar observasi tersebut sesuai dengan 
Permendiknas Nomor 24 Tahun 2007 tentang Sarana dan Prasarana Laboratorium.

Lembar observasi manajemen penataan alat dan bahan praktikum ini memuat 42 alat praktikum disertai dengan standar penataan alat praktikum tersebut yang dikutip dari berbagai sumber. Setiap alat praktikum dilengkapi dengan empat hingga lima standar penataan. Pada kolom kesesuaian diisi sesuai data pengamatan apakah penataannya sesuai standar atau tidak. Lembar observasi manajemen penataan bahan ini memuat bahan-bahan yang digunakan pada praktikum, yang dikelompokkan berdasarkan wujud zat tersebut baik padatan maupun cairan. Setiap bahan praktikum tersebut disertai dengan kriteria penataan bahan yang dikutip dari berbagai sumber.

Instrumen manajemen adminstrasi laboratorium ini terdiri dari lembar observasi administrasi alat dan bahan yang berisi 14 jenis perangkat administrasi serta lembar observasi administrasi ketenagakerjaan.

Selain lembar observasi instrumen angket digunakan untuk mengukur efektivitas penggunaan laboratorium kimia. Angket ini ditujukan kepada guru dan siswa kelas X, XI dan XII sesuai dengan praktikum yang harus dilaksanakan yang sebelumnya dibuat kisi-kisi sesuai dengan silabus kurikulum nasional.

\section{HASIL DAN PEMBAHASAN}

Berdasarkan hasil data yang diperoleh tentang kelengkapan alat bahan praktikum di SMA dapat dilihat pada Gambar 1.

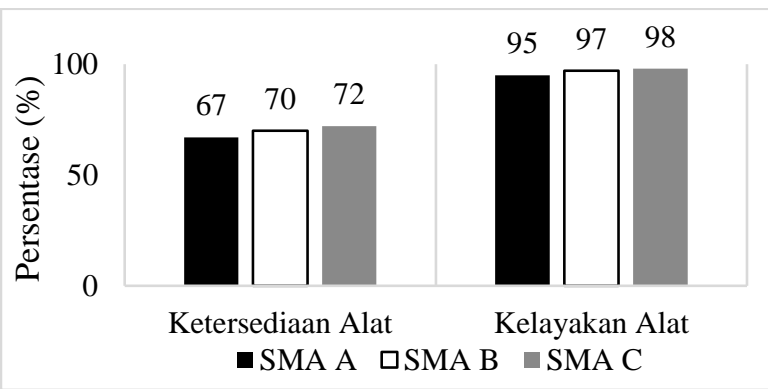

Gambar 1. Persentase Kelengkapan Alat Kimia

Secara umum ketersediaan alat praktikum kimia di tiga SMA wilayah Sumedang termasuk kategori lengkap $(69,67 \%)$ dengan kondisi sangat baik (96,6\%). Ketersediaan alat praktikum ini dibandingkan dengan acuan dari Permendiknas Nomor 24 Tahun 2007. Secara umum, di SMA Wilayah Sumedang tidak tersedia beberapa alat seperti set destilasi, dan alat elektronik seperti multimeter. Tidak tersedianya beberapa alat menjadi penghambat dalam beberapa materi praktikum.

Data kelengkapan bahan praktikum kimia di SMA Wilayah Sumedang dapat dilihat pada Gambar 2.

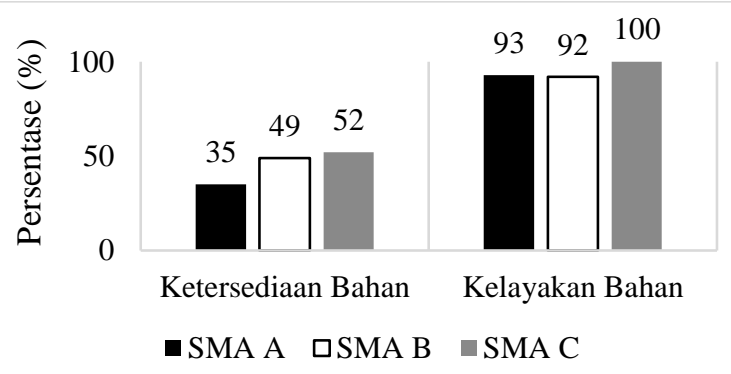

\section{Gambar 2. Persentase Kelengkapan Bahan Kimia}

Secara umum ketersediaan bahan praktikum kimia tergolong kategori kurang lengkap $(45,3 \%)$ meskipun dalam kondisi sangat baik $(95 \%)$. Secara umum beberapa bahan baik padatan maupun cairan tidak tersedia. Dalam artian bahan-bahan yang digunakan untuk pelaksanaan praktikum sesuai kurikulum nasional. Pada beberapa sekolah juga terdapat bahan praktikum yang banyak namun tidak diperlukan dalam praktikum.

Data hasil penataan alat praktikum kimia di laboratorium SMA wilayah Sumedang dapat dilihat pada Gambar 3.

Berdasarkan grafik pada Gambar 3, secara umum penataan alat praktikum kimia tergolong kategori sangat baik (81\%). Secara umum dari ketiga sekolah tersebut ketidaksesuaian terjadi pada penataan alat di berbagai golongan. Padahal penyimpanan alat harus dikelompokkan berdasarkan golongannya 
masing-masing agar memudahkan dalam pencarian alat-alat praktikum (Adisendjaja, 2008).

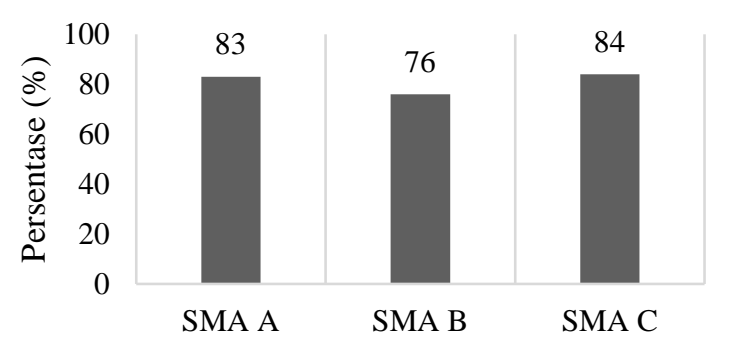

Gambar 3. Persentase Penataan Alat Kimia

Berdasarkan Gambar 1. ketersediaan alat kimia secara umum di SMA A 67\% dikategorikan dalam kategori lengkap. Menurut Hamidah dkk. (2013) persentase 5074,9 dikategorikan lengkap. Selain itu sesuai dengan analisis silabus kurikulum nasional ada 42 jenis alat praktikum kimia yang dibutuhkan untuk menunjang kegiatan praktikum di SMA, sedangkan di SMA A hanya tersedia 25 jenis alat.

Alat-alat praktikum kimia yang tersedia di SMA A sebanyak 25 jenis ini terdiri dari alat golongan kaca, karet, plastik, keramik, elektronik, besi, kertas, dan kayu. Hal ini selaras dengan apa yang dipaparkan Suprayitno (2010), di laboratorium kimia alatalat praktikum dikelompokkan ke dalam 8 golongan, yaitu alat-alat yang terbuat dari kaca, karet, keramik, plastik, elektronik, besi, kayu dan kertas.

Data hasil penataan bahan praktikum kimia di laboratorium SMA wilayah Sumedang dapat dilihat pada grafik dibawah ini:

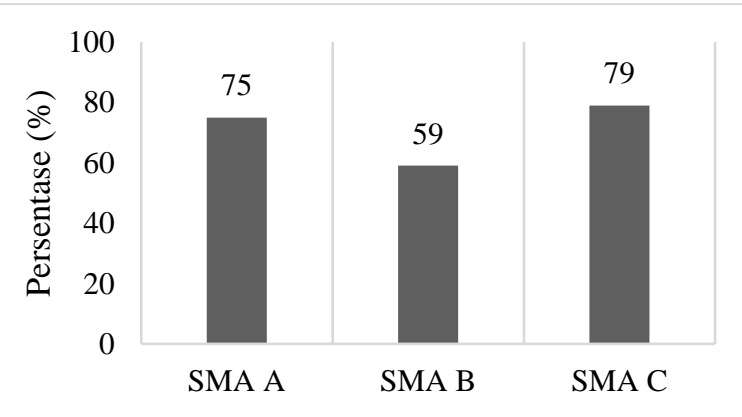

Gambar 4. Persentase Penataan Bahan Kimia
Berdasarkan grafik tersebut secara umum penataan bahan praktikum tergolong kategori baik $(71 \%)$. Secara umum dari ketiga sekolah tersebut ketidaksesuaian terjadi pada bahan cairan. Penyimpanan bahan-bahan kimia juga pada beberapa SMA tidak pada ruangan berventilasi. Padahal seharusnya penyimpanan bahan-bahan kimia haruslah dalam ruangan berventilasi baik untuk mencegah terjadinya kecelakaan di laboratorium kimia (Darmawan, 2014).

Dalam hal manajemen penataan bahan kimia di SMA A tergolong dalam kategori sangat baik, contohnya untuk bahan padatan dan cairan penyimpanannya dipisahkan. Walaupun dalam satu lemari tapi penyimpannya berjauhan. Namun sayangnya di SMA A ruangan bahan tidak berventilasi, sedangkan menurut Kertiasa (2006) penyimpanan bahan-bahan kimia haruslah dalam ruangan berventilasi baik untuk mencegah terjadinya kecelakaan di laboratorium kimia.

Selain itu, untuk bahan golongan cairan terkait dengan pelabelan bahan dan penyimpanan bahan cair seperti asam kuat, tidak adanya lemari asam maka penyimpanan tidak dilakukan di lemari asam hanya pada lemari rak biasa padahal menurut Suprayitno (2010:54) beberapa zat yang dapat mencemari udara di dalam laboratorium seperti asam klorida pekat harus disimpan dalam lemari asam.

Data hasil administrasi alat bahan praktikum di laboratorium kimia dapat dilihat pada grafik dibawah ini:

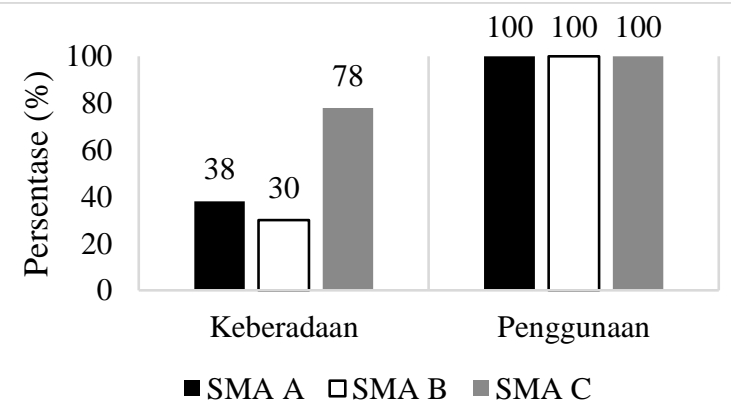

Gambar 5. Persentase Administrasi Alat Bahan Kimia 
Secara umum manajemen administrasi alat bahan praktikum tergolong kategori kurang lengkap (48,6\%), karena tidak terdapatnya 18 jenis pengadministrasian. Namun dalam penggunaannya efektif walaupun hanya beberapa pengadministrasian yang tersedia.

Analisis manajemen administrasi dalam penelitian ini terkait manajemen administrasi alat dan bahan dan administrasi ketenagakerjaaan. Manajemen administrasi alat dan bahan di SMA A tergolong kategori kurang lengkap, karena hanya tersedia tujuh buku administrasi dari 18 jenis pengadministrasian alat dan bahan sesuai dengan yang dipaparkan oleh Yunita (2013:43-47) bahwa ada 18 buku catatan untuk pengadministrasian alat dan bahan praktikum kimia. Penggunaan buku adminstrasi alat dan bahan praktikum kimia ini sangat efektif karena digunakan dalam kegiatan di laboratorium kimia.

Data hasil administrasi ketenagakerjaan di laboratorium kimia dapat dilihat pada grafik dibawah ini:

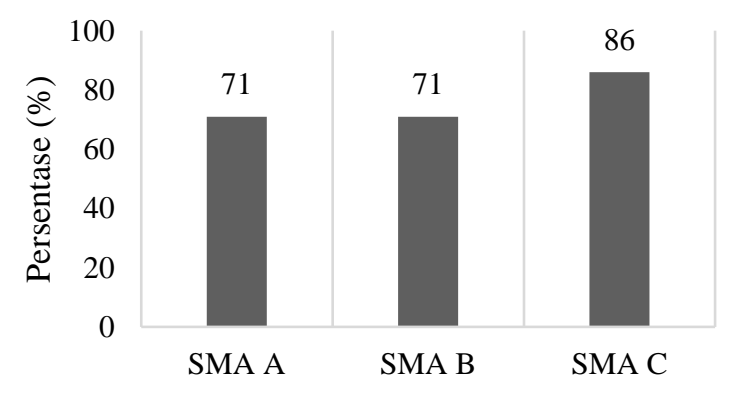
Gambar 6. Persentase Administrasi
Ketenagakerjaan

Secara umum administrasi ketenagakerjaan tergolong kategori sangat lengkap (76\%). Persamaannya tidak terdapat teknisi laboratorium di SMA Wilayah Sumedang. Perbedaannya tidak terdapatnya laboran pada beberapa SMA. Laboran berperan dalam mengerjakan administrasi tentang alat dan bahan. Ditambah dengan kurang lengkapnya administrasi alat bahan membuat jumlah alat bahan yang tersedia di laboratorium tidak terpantau dengan baik (Khamidinal, 2009).
Data hasil efektivitas penggunaan laboratorium kimia di SMA wilayah Sumedang dapat dilihat pada grafik dibawah ini:

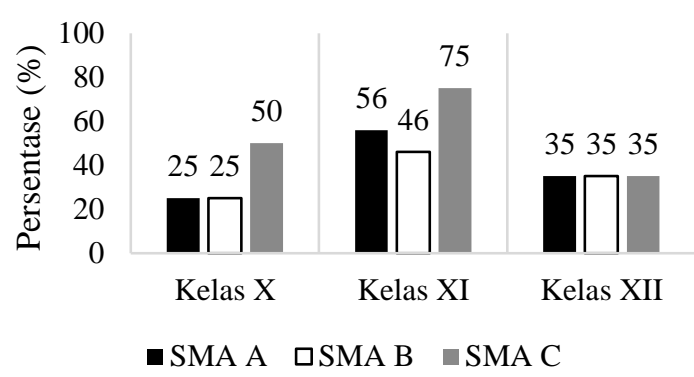

Gambar 7. Persentase Efektivitas Penggunaan Laboratorium Kimia

Secara umum efektivitas penggunaan laboratorium di SMA Wilayah Sumedang tergolong kategori kurang efektif $(42,4 \%)$. Pada beberapa materi praktikum tidak dilaksanakan. Praktikum yang relatif jarang disebabkan oleh beberapa hal, dalam ketersediaan alat dan bahan juga dalam hal penataan. Karena ketersediaan alat berpengaruh terhadap efektivitas penggunaan laboratorium (Darsana dkk., 2014).

Selain itu bukan hanya dalam hal tersebut saja, namun juga dari sudut pandang guru kimianya sendiri, apakah praktikum bisa diganti dengan kegiatan pembelajaran lain seperti demonstrasi atau menggunakan media. Selain itu waktu yang diperlukan dalam persiapan alat dan bahan untuk praktikum tersebut. Adisendjaja (2008) mengatakan bahwa pada umumnya kendala dalam pelaksanaan praktikum adalah waktu yang sangat menyita sehingga berketetapan untuk menggunakan waktu yang tersedia seefektif mungkin agar mampu menyelesaikan materi pelajaran sesuai tuntutan kurikulum. Berdasarkan wawancara dengan guru kimia di SMA A, guru merasa kerepotan dalam hal mempersiapkan alat dan bahan untuk praktikum karena tidak adanya laboran sedangkan kelas yang diampunya tidak hanya satu atau dua kelas dalam sehari pembelajaran (Adisendjaja, 2008). 
Hal serupa terkait efektivitas penggunaan laboratorium di SMA B yang tergolong kategori kurang efektif untuk kelas X, XI dan XII disebabkan karena kurangnya waktu guru kimia untuk melakukan praktikum serta banyaknya waktu yang diperlukan untuk menyediakan alat dan bahan untuk praktikum. Selain itu di SMA B hanya ada tiga guru kimia sedangkan satu guru kimia ditugaskan pula sebagai wakil kepala sekolah bagian kurikulum sehingga kewajiban mengajar untuk guru tersebut hanya 12 jam pelajaran dalam seminggu atau hanya berkewajiban mengajar untuk tiga kelas saja. Menurut penelitian Rezeqi bahwa keterbatasan waktu guru dalam mengajar di kelas juga berpengaruh terhadap kegiatan praktikum yang dianggap menyita waktu dalam hal persiapan (Rahmiyati, 2008).

Hal lain yang mempengaruhi efektivitas penggunaan laboratorium kimia juga disebabkan dari sulitnya mencari alat-alat yang diperlukan untuk praktikum karena penataan alat dan bahan yang kurang baik, Ajeng (2015) memaparkan bahwa penataan yang baik dapat memudahkan dalam kegiatan laboratorium.

Ketersediaan alat praktikum kimia di SMA B secara umum $70 \%$ dikategorikan dalam kategori lengkap menurut Hamidah dkk. (2011) persentase 50-74,9 dikategorikan lengkap. Terdapat 29 dari 42 jenis alat praktikum kimia sesuai dengan analisis silabus kurikulum nasional yang dibutukan untuk menunjang kegiatan prakikum di SMA (Hamidah dkk., 2013). Alat-alat praktikum kimia yang tersedia di SMA B sebanyak 29 jenis ini terdiri dari alat golongan kaca, karet, plastik, keramik, elektronik, besi, kertas, dan kayu. Hal ini selaras dengan apa yang dipaparkan sebelumnya bahwa menurut Suprayitno, di laboratorium kimia alat-alat praktikum kimia dikelompokkan kedalam 8 golongan, yaitu alat-alat yang terbuat dari kaca, karet, keramik, plastik, elektronik, besi, kayu dan kertas (Suprayitno, 2010).

\section{KESIMPULAN}

Efektivitas penggunaan laboratorium kimia di SMA Wilayah Sumedang tergolong kategori kurang efektif (42,4\%). Ditinjau dari ketersediaan alat praktikum, laboratorium kimia di SMA wilayah Sumedang tergolong kategori lengkap (69,67\%), ketersediaan bahan tergolong kategori kurang lengkap $(45,3 \%)$. Dalam hal penataan alat kimia di SMA wilayah Sumedang tergolong kategori sangat baik $(81 \%)$, sedangkan penataan bahan tergolong kategori baik (71\%). Pengadministrasian alat bahan tergolong kategori kurang lengkap (48,6\%), terkait administrasi ketenagakerjaan tergolong kategori sangat lengkap (76\%). Beberapa faktor lain juga mempengaruhi efektivitas dari penggunaan laboratorium kimia SMA di wilayah Sumedang. 


\section{DAFTAR PUSTAKA}

Adisendjaja, Y. H. (2008). Kegiatan praktikum dalam pendidikan sains. Bandung: Jurusan Pendidikan Biologi FPMIPA UPI.

Ajeng, Y. (2015). Pengelolaan Laboratorium di Sekolah Menengah Pertama Negeri 1 Sentolo Kabupaten Kulon Progo. Disertasi, Universitas Negeri Yogyakarta.

Barnawi, \& Arifin, M. (2012). Manajemen Sarana dan Prasarana Sekolah. Yogyakarta: Ar Farizi.

Chang, R., \& Overby. J, (2008). General Chemistry the Essential Concept. New York: Ryan Bankenship.

Darmawan, B. (2014). Manajemen Sarana dan Prasarana Dalam Meningkatkan Kualitas Pendidikan. [Online], diakses Jum'at Juli 2017.

Darsana, I. W., Sadia, I. W., Tika, I. N., \& Si, M. (2014). Analisis Standar Kebutuhan Laboratorium Kimia dalam Implementasi Kurikulum 2013 Di SMA Negeri Kabupaten Bangli. Jurnal Pendidikan IPA Indonesia, 4(1).

Depdiknas. (2004). Penataan Alat dan Bahan. Jakarta: Bagian Proyek Pengembangan Kurikulum Direktorat Pendidikan Menengah Kejuruan Direktorat Jenderal Pendidikan Dasar dan Menengah.

Halida, E. (2016). Analisis Peralatan Laboratorium Kimia SMA Negeri SeKecamatan Ngaglik Kabupaten Sleman. Disertasi, Universitas Negeri Yogyakarta.

Hamidah, A., Sari, N., \& Budianingsih, R. (2013). Manajemen Laboratorium Biologi Beberapa SMA Swasta di Kota Jambi. SAINMATIKA/ Jurnal Sains dan Matematika, $7(1)$.

Hofstein, A., \& Lunetta, V. N. (2004). The Laboratory in Science Education:

Foundations for the twenty-first century. Science education, 88(1), 2854.

Kertiasa, N. (2006). Laboratorium Sekolah dan Pengelolaannya Panduan bagi Guru dalam Membantu Merancang, Mengelola, Mengupayakan agar Laboratorium Sekolah Berfungsi lebih Efektif dalam Pembelajaran, dan Aman bagi Pemakainya. Bandung: Pudak Scientific.

Khamidinal. (2009). Teknik Laboratorium Kimia. Yogyakarta: Pustaka Pelajar.

Koesmadji, W. (2004). Teknik Laboratorium. Bandung: Universitas Pendidikan Indonesia.

Rahmiyati, S. (2008). Keefektifan Pemanfaatan Laboratorium di Madrasah Aliyah Yogyakarta. Jurnal Penelitian dan Evaluasi Pendidikan, 11(1).

Sagala, S. (2011). Konsep Dan Makna Pembelajaran. Bandung: Alfabeta.

Saleh, M., \& Emha, H. (2006). Pedoman Penggunaan Laboratorium Sekolah. Bandung: Remaja Rosdakarya.

Sari, S., Anjani, R., Farida, I., \& Ramdhani, M. A. (2017). Using Android-Based Educational Game for Learning Colloid Material. Journal of Physics: Conference Series, 895(1).

Sari., \& Yunita. (2015). Profil Laboratorium Madrasah Aliyah dan Sekolah Menegah Atas di Jawa Barat. Prosiding Simposium Nasional Inovasi dan Pembelajaran Sains. Bandung: Indonesia.

Suprayitno, T. (2010). Panduan Teknis Perawatan Peralatan Laboratorium Kimia SMA. Jakarta: Erlangga.

Ural, E. (2016). The Effect of Guided-Inquiry Laboratory Experiments on Science 
Education Students' Chemistry Laboratory Attitudes, Anxiety and Achievement. Journal of Education and Training Studies, 4(4), 217-227.

Wiersma, W., \& Jurs, S. G. (2005). Research Methods in Education: An Introduction. Boston New York.

Wiratma, I. G. L. (2015). Pengelolaan Laboratorium Kimia pada SMA Negeri di Kota Singaraja:(Acuan Pengembangan Model Panduan Pengelolaan Laboratorium Kimia Berbasis Kearifan Lokal Tri Sakti). JPI (Jurnal Pendidikan Indonesia), 3(2).

Yunita. (2013). Pengelolaan Laboratorium Sekolah. Bandung: CV Insan Mandiri. 